\title{
Estudo comparativo entre nível de desconforto e reflexo acústico em trabalhadores***
}

\author{
Comparative study between the level of discomfort and the acoustic \\ reflex in workers
}

Francisca Magnólia Diógenes Holanda Bezerra*

Maria Cecília Martinelli Iório**

*Fonoaudióloga. Mestre em Ciências dos Distúrbios da Comunicação Humana: Campo Fonoudiológico. Docente do Curso de Fonoaudiologia da Universidade de Fortaleza. Endereço para correspondência: Av. da Universidade, 3264 - Apto. 104 Bloco 3 - Fortaleza - Ceará -

CEP: 60.0201-81

(magnoliadiogenes@unifor.br).

**Fonoaudióloga. Doutora em Ciências dos Distúrbios da Comunicação Humana. Professor Adjunto do Departamento de Fonoaudiologia da Universidade Federal de São Paulo - Escola Paulista de Medicina.

***Trabalho realizado na Universidade Federal de São Paulo - Escola Paulista de Medicina.

Artigo de Pesquisa

Artigo Submetido a Avaliação por Pares

Conflito de Interesse: não

Recebido em 15.02.2005.

Revisado em 26.04.2005; 16.01.2006; 14.03.2006.

Aceito para Publicação em 14.03.2006.

\begin{abstract}
Background: comparative study between the level of discomfort and the acoustic reflex in workers. Aim: to observe the hearing behavior, through the assessment of the contraction activity of the stapedius muscle and the level of discomfort, of individuals who are and are not exposed to occupational noise, with the aim of identifying the influence of noise in the behavior of the contraction of the stapedius muscle and in the sensibility of hearing. Method: this study was developed at the Serviço Social da Indústria - SESI - Ce. A hundred and three adults with normal hearing, male and female, with ages varying from 18 to 45 years were divided in three groups: G1 with 41 adults exposed to noise and who used AIPE; G2 with 32 adults exposed to noise and who did not use AIPE; G3 with 30 adults who were not exposed to noise. Participants were submitted to audiologic evaluation, including the analysis of the acoustic reflex level (ARL) and discomfort level (DL) at the frequencies of $500 \mathrm{HZ}, 1000 \mathrm{~Hz}$, $2000 \mathrm{~Hz}, 3000 \mathrm{~Hz}, 4000 \mathrm{~Hz}$ and WN. For the statistical analysis the tests of Mann Whitney, Wilcoxon and Kruskal, with significance levels of $5 \%$, were used. Results: no statistically significant difference was identified for the ARL between the three groups, with mean values ranging from 93 to $103 \mathrm{dBHL}$; the ARL was significantly smaller than the DL, with the mean values of DL varying from 111 to 119 dBHL for G1, from 113 to $120 \mathrm{dBHL}$ for G2 and from 106 to $114 \mathrm{dBHL}$ for G3; the DL is higher in individuals of G1 followed by individuals of G2 and G3. Conclusion: the exposure to noise does not determine changes in the behavior of the ARL; the DL rises with the exposure to occupational noise; the DL is higher than the ARL in 10 to $25 \mathrm{~dB}$
\end{abstract}

Key Words: Acoustic Reflex; Hearing; Hearing Threshold.

\section{Resumo}

Tema: estudo comparativo do nível do desconforto e do limiar do reflexo acústico em trabalhadores. Objetivo: observar o comportamento auditivo por meio da avaliação da atividade da contração do músculo estapédio e do nível de desconforto em pessoas expostas e não expostas a ruído ocupacional, com intuito de identificar alguma influencia do ruído no comportamento da contração do músculo estapédio e na sensibilidade auditiva. Método: o estudo foi desenvolvido no Serviço Social da Indústria - SESI Ceará. Foram selecionados 103 adultos com audição normal, de ambos os sexos, na faixa etária de 18 a 45 anos distribuídos em três grupos: G1 com 41 adultos expostos a ruído que utilizavam EPIA, G2 com 32 adultos expostos a ruído que não utilizavam EPIA e G3 composto por 30 adultos não expostos. Os indivíduos foram submetidos à avaliação audiológica, tendo sido analisado o LRA e ND nas freqüências de $500 \mathrm{~Hz}, 1000 \mathrm{~Hz}, 2000 \mathrm{~Hz}, 3000 \mathrm{~Hz}, 4000 \mathrm{~Hz}$ e WN. A análise estatística foi realizada por meio dos testes de Mann Whitney, Wilcoxon e Kruskal com nível de significância em 5\%. Resultados: não houve diferença estatística significante entre os LRA obtidos nos três grupos, com valores médios de 93 a 103dBNA; o LRA foi significantemente menor que o ND, tendo valores médios para ND variando de 111 a 119dBNA no G1, de 113 a 120dBNA no G2 e 106 a 114dBNA no G3; o ND é maior nos indivíduos do grupo G1 seguidos pelos grupos G2 e G3. Conclusões: o ruído não determina alterações no comportamento do LRA; o ND é aumentado pela exposição ao ruído ocupacional; o ND é maior que o LRA de 10 a $25 \mathrm{~dB}$.

Palavras-Chave: Reflexo Acústico; Audição; Limiar Auditivo 


\section{Introduction}

The sensitivity and the vulnerability of the cochlea the damages caused for occupational noise have taken some researchers, to study on the possibility in evaluating and/or foreseeing the individual susceptibility or the auditive resistance as form of prevention of the sensorioneural auditory loss for elevated sound pressure level.

Musiek and Kintelman (2001) said that the muscle of the stapedius, contracts in the.presence of a enough strong sound bilaterally, this contraction cause a movement of platinum of the stapes for inside and for it are of the oval fenestra. This action limits the movement of the ossicula and attenuates the vibration of platinum of the stapes, reducing, thus, the movement of the liquids of the internal ear. The acoustic reflex has, therefore, the function to protect the internal ear of elevated sound pressure levels.

The acoustic reflex level (ARL) is the lesser intensity of the sonorous stimulus, that cause a change of the compliance of the media ear. As Katz (1999) the levels of intensity necessary to unchain the acoustic reflex in individuals with normal hearing are from 70 to $100 \mathrm{~dB}$ above of the hearing threshold, with medium value for ARL with contralateral stimulus for pure tone of, approximately, $85 \mathrm{dBHL}$ and $65 \mathrm{dBHL}$ for noise of broad band. The fact of the ARL to be lesser for the noise of broad band for pure tones, suggests that a specific relation exists between the width of the band of frequencies of the stimulus and the auditory protection. This leads to assume that the noise provokes a hearing behaviour differentiated depending on the specter of frequencies.

Another important measure when it is studied hearing of the exposed individuals the elevated sound pressure levels is the discomfort level (DL), where in normal people for a tone of $1000 \mathrm{~Hz}$ meets around $120 \mathrm{dBHL}$. According to Katz (1999), the mensuration of the DL is a psychoacoustics measure, that says respect to the biggest sound pressure level (SPL) that the citizen perceives without if bothering. Literature contains controversial datum and no conclusive how much to the relation between the DL and the ARL.

Uhles et al. (2000) had told that the ARL has little correlation with the measures of the discomfortable level of intensity sensation to allow a necessary forecast of the DL from the ARL. The variability of agreement of these measures depends on the used instruction for the measure of the DL, the type of used acoustic stimulus and of the degree of hearing loss of the patient.

Kumar and Barman (2002) had told that exactly patient with normal hearing or auditory loss of light degree they will be able to suffer from hypersensitivity the sounds, however recent research had shown that the use of generators of sound with white noise can help to abolish the hipersensitivity the sounds.

These training with sound generators results in a permanent readjustment of the intensity sensation, occurring in few months, an auditory desensitization raising the dynamic area of the hearing. This change can be proven by means of measures DL.

Individuals exposed the occupational noise, are subjects the changes in the levels of discomfort for continuous exposition the raised sound pressure levels exactly with normal hearing thresholds (Petrone, 1999). Therefore, noise becomes necessary to know the agent, the history of the patient exposed to the sound pressure level elevated and its effect in the organism physical.

The objective of the present study is to observe the hearing behaviour by means of the evaluation of the contraction of the estapédio muscle and the ND in people exposed and not exposed the noise occupational, with intention to identify some influence of the noise in the behaviour of the contraction of the stapedius muscle in auditory sensitivity.

\section{Methods}

The study it was carried through in the Service Social da Indústria SESI-CE and approved by the Committee of Ethics of the Universidade Federal of São Paulo, under code CEP n ${ }^{\circ} 0485 / 02$, dated in 30 of May of 2003. The participants had been clarified anticipatedly on the procedures to be carried through and, being aware and with its had assent, the research was initiated.

For the composition of the sample, the following criteria of eligibility had been established: bilateral hearing thresholds of until $25 \mathrm{dBHL}$ in the frequencies from 500 to $8000 \mathrm{~Hz}$; tympanometric curve of the An type and acoustic reflex presents in the frequencies from 500 to $2000 \mathrm{~Hz}$; exposition to the occupational noise of the continuous type, above of $85 \mathrm{dBHL}$, with daily day of work of eight hours, for more than three years, users or not of auricular individual protection equipment (AIPE) 
of the type plug or shell and acoustic rest of at the very least 14 hours.

73 exposed individuals had been evaluated the occupational noise, that if fit in the above described criteria of eligibility, and others 30 individuals with the same characteristics, except for the exposition the occupational noise and that they had constituted the group have controlled to allow the comparisons intended in the present study.

This sample of 103 individuals of both the sexes with ages from 18 to 45 years was distributed in three groups: G1 composed for 41 adults esposed the noise who used the AIPE, G2 32 adults exposed the noise who did not use the AIPE and the G3 composed for 30 adults not exposed the noise above of $85 \mathrm{~dB}$.

The evaluation was initiated with the inspection of the external acoustic meatus (EAM) in order to discard presence of strange bodies or the existence of cerumen excess, which could compromise the accomplishment of the considered tests.

After that anamnesis was carried through one occupational physician to investigate possible last occurrences and/or presents of: otalgia, itch, auricular fullness, difficulty in hearing and/or understanding the people speaking, sensitivity the sounds of strong intensity, presence of humming or giddiness. It was also verified if the individual after related some physical or emotional alteration during or the hours of working, hereditary antecedent, diabetes, arterial hypertension, if it had expositions it are of the environment of work and/ or another type of responsible agent for auditory alterations as: chemical products and ototoxics medicine use.

To follow the research of the thresholds of audibility for air way was carried through. The individual was located in a cabin acousticly treated in accordance with norm ISO 8253.1, and after the rank of the phones had been searched the audibility thresholds, using modulated pure tones in frequency (warble), presented in the following order: $1000 \mathrm{~Hz}, 2000 \mathrm{~Hz}, 3000 \mathrm{~Hz}, 4000 \mathrm{~Hz}, 6000 \mathrm{~Hz}$, $8000 \mathrm{~Hz}$ and $500 \mathrm{~Hz}$, with use of the described descending technique for Katz (1999). The DL was searched using pure tones modulated, that had been presented in ascending way in the frequencies of $1000 \mathrm{~Hz}, 2000 \mathrm{~Hz}, 3000 \mathrm{~Hz}, 4000 \mathrm{~Hz}, 500 \mathrm{~Hz}$ and white noise $(\mathrm{WN})$ in intervals of $5 \mathrm{~dB}$. It was considered as DL the first level of hearing in which the individual related discomfort.

The tone was carried through the tympanometry using investigates of $226 \mathrm{~Hz}$ and had been searched the ARL in the contralateral way in the frequencies of $500 \mathrm{~Hz}, 1000 \mathrm{~Hz}, 2000 \mathrm{~Hz}, 3000 \mathrm{~Hz}$, $4000 \mathrm{~Hz}$ and $\mathrm{WN}$.

For the audiologic evaluation and the research of the DL the audiometer of the Interacoustics mark was used model AC 40, with use of phone TDH 39 (ANSI S3 1987) and for the accomplishment of immittanciometry: tympanometry and the research of the LRA, immittanciometer of Interacoustics mark 26 model AZ and phone TDH 39. Both the equipment (audiometer and immittanciometer), calibrated as norm ANSI 1969.

In the comparative study between two populations the data had been analyzed by means of the tests distribution free of Mann Whitney and Wilcoxon, and for the study of three populations by means of the test of Kruskal Wallis. The level of significance in $5 \%$ was established.

\section{Results}

Study of the acoustic reflex

The study of the acoustic consequence it is presented in Table 1.

Study of the DL

The study of the DL according to presence or the absence is presented in Table 2.

In Table 3 the arithmetic means of the DL and respective shunting lines are presented standard for frequency, for the sides right and left, the groups G1, G2 and G3.

Comparative study between the acoustic reflex and the DL

The thresholds of the average reflex and DLs had been compared for each one of the groups and after that the differences between the ARL and the DL had been analyzed. The results are presented in Table 4. 
TABLE 1. Medium and pattern deflection of the acoustic reflex level for frequency for the ears right and left in the groups G1, G2 and G3.

\begin{tabular}{|c|c|c|c|c|c|c|c|c|}
\hline & \multirow[t]{2}{*}{ LRA } & \multicolumn{2}{|c|}{\begin{tabular}{|c|} 
Não Exposto \\
G3 \\
\end{tabular}} & \multicolumn{2}{|c|}{$\begin{array}{l}\text { Exposto sem EPIA } \\
\text { G2 }\end{array}$} & \multicolumn{2}{|c|}{$\begin{array}{l}\text { Exposto com EPIA } \\
\text { G1 }\end{array}$} & \multirow[t]{2}{*}{$\mathrm{P}$} \\
\hline & & média & \begin{tabular}{|l|} 
desvio-padrão \\
\end{tabular} & média & \begin{tabular}{|l|} 
desvio-padrão \\
\end{tabular} & média & desvio-padrão & \\
\hline \multirow{2}{*}{$500 \mathrm{~Hz}$} & direita & 95,6667 & 8,6834 & 95,6250 & 8,8673 & 93,4878 & 16,7334 & 0,883 \\
\hline & esquerda & 96,0000 & 9,4139 & 93,9063 & 8,6821 & 96,2195 & 9,0678 & 0,764 \\
\hline \multirow{2}{*}{$1000 \mathrm{~Hz}$} & direita & 95,3333 & 9,9076 & 95,4688 & 8,3627 & 95,8537 & 7,7381 & 0,944 \\
\hline & esquerda & 96,3333 & 9,5532 & 94,2188 & 8,8088 & 93,5366 & 9,4369 & 0,233 \\
\hline \multirow{2}{*}{$2000 \mathrm{~Hz}$} & direita & 93,3333 & 11,3967 & 93,9063 & 10,0590 & 93,0488 & 9,0746 & 0,917 \\
\hline & esquerda & 96,5000 & 9,4823 & 93,9062 & 9,5659 & 93,2927 & 10,1618 & 0,140 \\
\hline \multirow{2}{*}{$3000 \mathrm{~Hz}$} & direita & 94,5000 & 10,7759 & 95,7813 & 10,2477 & 93,9024 & 12,5256 & 0,629 \\
\hline & esquerda & 96,1667 & 10,8821 & 95,4688 & 10,1090 & 95,8537 & 12,2425 & 0,978 \\
\hline \multirow{2}{*}{$4000 \mathrm{~Hz}$} & direita & 99,5000 & 10,9348 & 96,8750 & 10,9065 & 102,5610 & 16,3218 & 0,339 \\
\hline & esquerda & 100,8333 & 11,3778 & 97,1875 & 10,9939 & 103,7805 & 14,4819 & 0,064 \\
\hline \multirow{2}{*}{ WN } & direita & 96,3333 & 9,5532 & 96,4062 & 8,2535 & 94,1463 & 9,4142 & 0,668 \\
\hline & esquerda & 97,1667 & 9,7099 & 95,3125 & 8,5135 & 95,9756 & 9,2344 & 0,854 \\
\hline
\end{tabular}

*Kruskal Wallis Test.

TABLE 2. The patients' distribution (\%) according the presence and absence of discomfort level (DL) for frequency for the ears right and left for the groups G1, G2 and G3.

\begin{tabular}{|c|c|c|c|c|c|c|c|c|c|c|c|c|c|c|c|}
\hline & \multirow{3}{*}{ D } & \multicolumn{6}{|c|}{ Orelha Direita } & \multirow{3}{*}{$\mathrm{P}^{*}$} & \multicolumn{6}{|c|}{ Orelha Esquerda } & \multirow{3}{*}{$\mathrm{P}^{*}$} \\
\hline & & \multicolumn{2}{|c|}{ Não Exposto } & \multicolumn{2}{|c|}{$\begin{array}{l}\text { Exposto sem } \\
\text { EPIA } \\
\end{array}$} & \multicolumn{2}{|c|}{$\begin{array}{c}\text { Exposto com } \\
\text { EPIA } \\
\end{array}$} & & \multicolumn{2}{|c|}{ Não Exposto } & \multicolumn{2}{|c|}{$\begin{array}{c}\text { Exposto sem } \\
\text { EPIA } \\
\end{array}$} & \multicolumn{2}{|c|}{$\begin{array}{c}\text { Exposto com } \\
\text { EPIA } \\
\end{array}$} & \\
\hline & & Freq & $\%$ & Freq & $\%$ & Freq & $\%$ & & Freq & $\%$ & Freq & $\%$ & Freq & $\%$ & \\
\hline \multirow{3}{*}{$\begin{array}{l}\mathrm{ND} \\
500 \mathrm{HZ}\end{array}$} & $\mathrm{N}$ & 3 & 10,0 & 8 & 25,0 & 13 & 31,7 & \multirow{3}{*}{0,098} & 4 & 13,3 & 11 & 34,4 & 12 & 29,3 & \multirow{3}{*}{0,144} \\
\hline & S & 27 & 90,0 & 24 & 75,0 & 28 & 68,3 & & 26 & 86,7 & 21 & 65,6 & 29 & 70,7 & \\
\hline & TOTAL & 30 & 100,0 & 32 & 100,0 & 41 & 100,0 & & 30 & 100,0 & 32 & 100,0 & 41 & 100,0 & \\
\hline \multirow{3}{*}{$\begin{array}{l}\mathrm{ND} \\
1000 \mathrm{~Hz}\end{array}$} & $\mathrm{~N}$ & 5 & 16,7 & 13 & 40,6 & 6 & 14,6 & \multirow{3}{*}{$0,020^{*}$} & 5 & 16,7 & 15 & 46,9 & 13 & 31,7 & \multirow{3}{*}{$0,039 *$} \\
\hline & S & 25 & 83,3 & 19 & 59,4 & 35 & 85,4 & & 25 & 83,3 & 17 & 53,1 & 28 & 68,3 & \\
\hline & TOTAL & 30 & 100,0 & 32 & 100,0 & 41 & 100,0 & & 30 & 100,0 & 32 & 100,0 & 41 & 100,0 & \\
\hline \multirow{3}{*}{$\begin{array}{l}\text { ND } \\
2000 \mathrm{~Hz}\end{array}$} & $\mathrm{~N}$ & 6 & 20,0 & 16 & 50,0 & 13 & 31,7 & \multirow{3}{*}{$0,041^{*}$} & 5 & 16,7 & 18 & 56,3 & 19 & 46,3 & \multirow{3}{*}{$0,004 *$} \\
\hline & $\mathrm{S}$ & 24 & 80,0 & 16 & 50,0 & 28 & 68,3 & & 25 & 83,3 & 14 & 43,8 & 22 & 53,7 & \\
\hline & TOTAL & 30 & 100,0 & 32 & 100,0 & 41 & 100,0 & & 30 & 100,0 & 32 & 100,0 & 41 & 100,0 & \\
\hline \multirow{3}{*}{$\begin{array}{c}\mathrm{ND} \\
3000 \mathrm{~Hz}\end{array}$} & $\mathrm{~N}$ & 7 & 23,3 & 17 & 53,1 & 16 & 39,0 & \multirow{3}{*}{$0,055^{*}$} & 8 & 26,7 & 19 & 59,4 & 21 & 51,2 & \multirow{3}{*}{$0,027^{*}$} \\
\hline & S & 23 & 76,7 & 15 & 46,9 & 25 & 61,0 & & 22 & 73,3 & 13 & 40,6 & 20 & 48,8 & \\
\hline & TOTAL & 30 & 100,0 & 32 & 100,0 & 41 & 100,0 & & 30 & 100,0 & 32 & 100,0 & 41 & 100,0 & \\
\hline \multirow{3}{*}{$\begin{array}{c}\mathrm{ND} \\
4000 \mathrm{~Hz}\end{array}$} & $\mathrm{~N}$ & 10 & 33,3 & 19 & 59,4 & 23 & 56,1 & \multirow{3}{*}{0,080} & 14 & 46,7 & 20 & 62,5 & 26 & 63,4 & \multirow{3}{*}{0,310} \\
\hline & $\mathrm{S}$ & 20 & 66,7 & 13 & 40,6 & 18 & 43,9 & & 16 & 53,3 & 12 & 37,5 & 15 & 36,6 & \\
\hline & TOTAL & 30 & 100,0 & 32 & 100,0 & 41 & 100,0 & & 30 & 100,0 & 32 & 100,0 & 41 & 100,0 & \\
\hline \multirow{3}{*}{$\begin{array}{l}\text { ND } \\
\text { WN }\end{array}$} & $\mathrm{N}$ & 5 & 16,7 & 11 & 34,4 & 12 & 29,3 & \multirow{3}{*}{0,272} & 4 & 13,3 & 14 & 43,8 & 9 & 22,0 & \multirow{3}{*}{$0,018^{*}$} \\
\hline & S & 25 & 83,3 & 21 & 65,6 & 29 & 70,7 & & 26 & 86,7 & 18 & 56,3 & 32 & 78,0 & \\
\hline & TOTAL & 30 & 100,0 & 32 & 100,0 & 41 & 100,0 & & 30 & 100,0 & 32 & 100,0 & 41 & 100,0 & \\
\hline
\end{tabular}

*Teste Qui-quadrado de Pearson 
TABLE 3. Medium and pattern deflection of discomfort level for frequency for the ears right and left in the groups G1, G2 and G3.

\begin{tabular}{|c|c|c|c|c|c|c|c|c|}
\hline & \multirow{2}{*}{ ND } & \multicolumn{2}{|c|}{ Não Exposto } & \multicolumn{2}{|c|}{ Exposto sem EPIA } & \multicolumn{2}{|c|}{ Exposto com EPIA } & \multirow{2}{*}{$\mathrm{P}^{*}$} \\
\hline & & Média & Desvio-Padrão & Média & Desvio-Padrão & Média & Desvio-Padrão & \\
\hline \multirow{2}{*}{$500 \mathrm{~Hz}$} & direita & 110,8333 & 8,9137 & 114,8438 & 9,7123 & 114,7561 & 9,7437 & 0,102 \\
\hline & esquerda & 111,8333 & 10,2118 & 116,5625 & 7,7707 & 115,8537 & 9,1448 & 0,120 \\
\hline \multirow{2}{*}{$1000 \mathrm{~Hz}$} & direita & 110,1667 & 10,5441 & 117,3438 & 8,3264 & 114,3902 & 9,2328 & $0,016^{*}$ \\
\hline & esquerda & 112,6667 & 10,8066 & 119,2187 & 7,0835 & 117,0732 & 9,1498 & $0,020^{*}$ \\
\hline \multirow{2}{*}{$2000 \mathrm{~Hz}$} & direita & 111,5000 & 11,8285 & 118,5937 & 8,9112 & 115,4878 & 9,7983 & $0,019 *$ \\
\hline & esquerda & 114,5000 & 10,2006 & 119,6875 & 7,7186 & 118,0488 & 8,6514 & $0,027 *$ \\
\hline \multirow{2}{*}{$3000 \mathrm{~Hz}$} & direita & 113,1667 & 12,4902 & 119,5312 & 8,0682 & 116,9512 & 9,6746 & $0,046^{*}$ \\
\hline & esquerda & 114,3333 & 11,6511 & 120,1563 & 7,3489 & 118,5366 & 8,9613 & $0,031 *$ \\
\hline \multirow{2}{*}{$4000 \mathrm{~Hz}$} & direita & 114,8333 & 12,5591 & 119,8438 & 8,6588 & 118,6585 & 9,9388 & 0,094 \\
\hline & esquerda & 114,8333 & 13,2927 & 120,7812 & 7,6316 & 119,0244 & 10,1378 & 0,163 \\
\hline \multirow{2}{*}{ WN } & direita & 106,6667 & 13,1525 & 113,7500 & 11,9812 & 112,0732 & 13,2748 & 0,063 \\
\hline & esquerda & 106,5000 & 12,5362 & 114,8437 & 12,5393 & 111,5854 & 12,4719 & $0,015^{*}$ \\
\hline
\end{tabular}

*Kruskal Wallis Test.

TABLE 4. Results of Tukey's statistics for comparison of the diference between the acoustic reflex level and discomfort level.

\begin{tabular}{|c|c|c|}
\hline Variável & Grupos & $\mathrm{P}^{*}$ \\
\hline \multirow{3}{*}{ NDLRA 1} & não exposto $\mathrm{x}$ exposto sem EPIA & $0,050^{*}$ \\
\hline & não exposto $\mathrm{x}$ exposto com EPIA & 0,386 \\
\hline & exposto sem epia $\mathrm{x}$ exposto com EPIA & 0,447 \\
\hline \multirow{3}{*}{ NDLRA 1} & não exposto $\mathrm{x}$ exposto sem EPIA & $0,022 *$ \\
\hline & não exposto $\mathrm{x}$ exposto com EPIA & $0,050 *$ \\
\hline & exposto sem epia x exposto com EPIA & 0,875 \\
\hline \multirow{3}{*}{ NDLRA 2} & não exposto $\mathrm{x}$ exposto sem EPIA & 0,058 \\
\hline & não exposto $\mathrm{x}$ exposto com EPIA & 0,090 \\
\hline & exposto sem epia $\mathrm{x}$ exposto com EPIA & 0,942 \\
\hline \multirow{3}{*}{ NDLRA 4} & não exposto $\mathrm{x}$ exposto sem EPIA & $0,017 *$ \\
\hline & não exposto $\mathrm{x}$ exposto com EPIA & 0,923 \\
\hline & exposto sem epi $x$ exposto com EPIA & $0,028^{*}$ \\
\hline \multirow{3}{*}{ NDLRAWN } & não exposto $\mathrm{x}$ exposto sem EPIA & $0,050 *$ \\
\hline & não exposto $\mathrm{x}$ exposto com EPIA & 0,274 \\
\hline & exposto sem epia x exposto com EPIA & 0,588 \\
\hline
\end{tabular}

*Tukey Test 


\section{Discussion}

Discussion on the acoustic reflex

The study of the threshold of the gotten acoustic reflex in the three groups discloses values middle varying of, approximately, $93 \mathrm{dBHL}$ the 103 dBHL not having significant difference statistictly between the groups G1, G2 and G3 (Table 1).

In accordance with Meneguello et al. (2001) the middle of the acoustic reflex in normal individuals varies from 62 to $114 \mathrm{dBHL}$; for Komasec et al. (2001) from 80 the $90 \mathrm{dBHL}$; Olsen (1999) praises 85 dBHL; Musiek and Rintelmann (2001) tell that the middle of the acoustic reflex varies from 80 to $90 \mathrm{dBHL}$ for pure tone and to WN from 70 to $75 \mathrm{dBHL}$ differing from the findings in the studied groups.

Of this form, it can be evidenced that it has a small variation between the findings of the carried through studies in individuals with normal hearing, disclosing that the middles of the ARL in absolute values can vary (Musiek; Rintelmann, 2001). For some authors, however, it is possible to foresee the hearing threshold (HT) for the ARL (Olsen, 1999).

It is always observed that independently of the studied group G1, G2 and G3 the biggest values of the ARL had occurred, in the frequency of $4000 \mathrm{~Hz}$, what it can be proven by the studies of Pizarro and Pizarro (2000). These authors had told that people exposed the noise can modify the acoustic reflex in $4000 \mathrm{~Hz}$, being able this frequency to be modified or absent, exactly with the normal audiometry. Some authors had described that an auditory protection as resulted of the relation between the ARL exists and the function of the system to cochlear efferent (Dominguez et al., 2001)

Also was verified that the gotten middle thresholds with activator signal WN had not been significantly lesser that the gotten ones in frequencies 500, 1000, 2000 and $3000 \mathrm{~Hz}$. Such results disagree with the findings of some authors as Katz (1999) and Musiek and Rintelmann (2001), which they had described that to unchain the acoustic reflex with noise of broad band a less intense stimulaton of $20 \mathrm{dBHL}$ of the one is necessary than would be used with activator signals of pure tones.

The findings of the present research had agreed to the findings of Petrone (1999), that found reflexes varying between 90 to $93 \mathrm{dBHL}$ for the group of not exposed the noise and from 100 to $118 \mathrm{dBHL}$ for the exposed ones. As Carvallo and Soares (2004) stimulus of high frequency generate reduction of the threshold of acoustic reflex in people with hearing inside of the limit of normality.

Discussion on the DL

Was observed that in the right ear it had significant difference in the incidence of people who had presented discomfort in 1000, 2000 and $3000 \mathrm{~Hz}$ considering the groups exposed and not exposed with and without auricular AIPE. It can be evidenced that the lesser incidence of people who had presented discomfort occurred in the three frequencies in the group exposed without AIPE. The same still it occurred in the frequency of 4000 $\mathrm{Hz}$ and $\mathrm{WN}$, even so not being the difference statistictly significant. In the left ear, similar behaviour was observed statistictly being evidenced significant difference in the incidence of the discomfort in the frequencies of 1000, 2000, $3000 \mathrm{~Hz}$ and WN. Only in the frequence of $500 \mathrm{~Hz}$, the behaviour was different in the two tested ears.

From the significant differences statistictly evidenced between the three groups, it was investigated, by means of the application of the test Qui-Quadrado of Pearson, where these differences had occurred. It can be observed that these had happened between the incidence of discomfort in the group exposed and not exposed without AIPE in the seven analyzed conditions. Already in the comparison between the incidence of discomfort in the groups not exposed and exposed with AIPE and between the group exposed without AIPE and exposed with AIPE, only significant differences in two of the seven studied conditions had been observed. In all the studied cases, always had bigger incidence of discomfort in the individuals less exposed the noise, want either, not exposed or exposed with protection. Similar results had found Domínguez et al. (2001), when they had carried through auditory training with WN.

These findings prove the hypothesis raised in the accomplishment of this work of that bigger exposed individuals would present DLs that individuals exposed or not protected of the exposition. This hypothesis also was proven by Meneguello et al. (2001) that they had told that the exposition the noise for long periods will help the brain to control the sensitivity of reply to the sound. Domínguez et al. (2001) described that the 
exposition to the noise modifies the DL increasing the dynamic area of the hearing.

Thus being is possible to agree with authors Knobel et al. (2003) that they believe that the use of auditory training with masking noise favors the desensitization of the airways.

In the study of the calculated middle discomfort for the three groups, for frequency, it was verified that the average values had varied from $106 \mathrm{dBHL}$ to $120 \mathrm{dBHL}$, being that, for the group not exposed, varied from 106 to $114 \mathrm{dBHL}$; for the exposed one without AIPE between 114 and $120 \mathrm{dBHL}$ and for exposed with AIPE from 111 to $119 \mathrm{dBHL}$ (Table 2). Similar result found Petrone (1999), when it evidenced that exposed individuals the noise presented discomfort level bigger that people not exposed.

In the comparative study of the gotten middle levels of discomfort in the three studied groups, as much in the right ear as in the left ear, and for $\mathrm{WN}$ in the right ear can be inferred that it did not have significant difference in the frequencies of 500 and $4000 \mathrm{~Hz}$. In the too much frequencies, the differences had been statistictly significant in both the ears, having been always the biggest values found in the group exposed without AIPE and the minors in the group not exposed. It was observed that the group that uses the auricular AIPE if places in the intermediate position (Table 3). Such finding leads to believe that the attenuation offered for the manufacturer, the criteria of ambient evaluation and the form of as these equipment is used by the worker will be able to influence the hearing behaviour (Olsen, 1999).

Comparative study between the acoustic reflex and the DL

In this study one evidenced that the threshold of the average acoustic reflex was significantly lesser that the middle of discomfort level in both the ears, for all the studied frequencies and groups.

In the study of the difference between the ARL and the DL, it can be observed that the differences in the exposed group had not varied of 9,33dBHL with WN $18,66 \mathrm{dBHL}$ in $3000 \mathrm{~Hz}$; in the group "Exposed without AIPE " of 17,34dBHL with WN the 25,78 in $2000 \mathrm{~Hz}$ and the group "Exposed with AIPE" of 15,24 dBHL in 4000 to $23,04 \mathrm{~Hz} \mathrm{dBHL}$ in $3000 \mathrm{~Hz}$. Thus being, the biggest differences had occurred in the group "Exposed without AIPE". Such result would be waited, a time that the discomfort was bigger in the group "exposed without AIPE". One knows that the discomfort level is modified with the experience, or either, the individual starts to tolerate higher levels of noise, as they believe Knobel and Sanchez (2002).

The comparative study of the difference between DL and ARL between the groups it disclosed significant differences only in the frequencies of 1000, 2000 and $4000 \mathrm{~Hz}$ in the left ear (Table 4). In the inquiry to identify between which groups the differences had occurred, were observed that these had happened more frequently between the group not exposed and the exposed one without AIPE. In only one of the situations $(4000 \mathrm{~Hz})$, these had been verified between the groups exposed without AIPE and exposed with AIPE. The groups exposed with AIPE and exposed had not presented similar behaviour, being the difference observed in the frequency of $1000 \mathrm{~Hz}$. In that it says respect to ARL to be lesser that DL, the findings of this study agree to the examine carefullied data to the literature as related by Katz (1999), Musiek and Rintelmann (2001) in its studies.

Al-azazi and Othmann (2000) had told that exists a relation between the threshold of the acoustic reflex and the sensation of intensity, suggesting that it can have in common neural passage of information between the sensation of intensity and acoustic reflex. Contradictly, Olsen (1999) had described that exists a statistictly significant correlation between acoustic reflex and the DL only in patients with hearing losses. With this it can be concluded that; the noise does not determine alterations in the behaviour of the acoustic reflex of the stapedius muscle, the DL is modified by the exposition to the bigger occupational noise being in exposed individuals the noise; the ND is greater that the threshold of the acoustic reflex; the difference between the discomfort level and the threshold acoustic reflex varies from 10 to $25 \mathrm{dBHL}$ being bigger in exposed individuals the elevated sound pressure levels. 


\section{Conclusion}

The noise does not determine alterations in the behaviour of the acoustic reflex of the stapedius muscle; the DL is modified by the exposition to the occupational noise being bigger in exposed individuals the noise; the DL is greater than the acoustic ARL; the difference between the DL and ARL varies from 10 to $25 \mathrm{dBHL}$ being bigger in exposed individuals the elevated sound pressure levels.

\section{References}

AL-AZAZI, M. F.; OTHMAN, B.M. Acoustic reflex threshold and loudness disconfort. Saudi. Med. J., v. 21, n. 3, p. 251-216, 2000.

CARVAllo, R. M. M.; SOARES, J. C. Efeito do estímulo facilitador no limiar de reflexo acústico. Rev. Bras. Otorrinolaringol., v. 70, n. 2, p. 200-206, 2004.

DOMÍNGUEZ, U.L.J.; RODRÍGUEZ, M.C.; VALLÉS, V.H.; IPARRAQUIRRE, B.V.; KANASTER, DEL O.J. Auditiry training with wide-band whait noise: effects on the pain thresshold and pure tone thresholds. Acta Otorrinilaringol. Esp., v. 52, n. 5, p. 410-417, 2001.

FEENEY M.P.; KEEFE, D.H. Estimating the acoustic reflex threshold from widwband measures of reflectance. Ear Hear, v. 22, n. 4, p. 316-332, 2001.

KATZ, J. Tratado de audiologia clínica. 4. ed. São Paulo: Manole, 1999. 832 p.

KNOBEL, K.A.B.; BRANCOF, C.A.; ALMEIDA, K. O uso de instrumento auditivos na terapia do zumbido e da hiparacusia. In: ALMEIDA, K.; IÓRIO, M.C.M. Próteses auditivas: fundamentos teóricos \& aplicações clínicas. 2. ed. São Paulo: Lovise, 2003. p. 229-252.

KNOBEL, K.A.B.; SANCHEZ, T. G. atuações das fonoaudiólogas de São Paulo (Brasil) na avaliação de pacientes com queixas de zumbidos e ou hipersensibilidade a sons. Pró-fono R. Atual. Cient., v. 14, n. 2, p. 215-224, 2002 .
KOMAZEC, Z.; MiloseviC, D.; PIliPoviC, D. Correlation of subjective and objective methods of evaluation hearing threshold. Med. Pregl., v. 54, n. 7/8, p. 332-337, 2001.

KUMAR, A.; BARMAN, A. Effect of efferent-induced changes on acoustical reflex. Int. J. Audiol., v. 41, n. 2, p. 144-147, 2002.

Meneguello, J.; DOMEniCO, M.L.D.; COSTA, C. M. Ocorrência de reflexo acústico alterado em desordens do processamento auditivo. R. Bras. Otorrinolarigol., v. 67, n. 6, p. 830-835, 2001.

MUSIEK, F.E.; RINTELMANN, W. Perspectivas atuais em avaliação auditiva. São Paulo: Manole, 2001. 522 p.

OLSEN, S.O. The relationship between the unconfortable loudness level and the acoustic reflex thres hold for pure tones in normally - hearing and impaired listeners-a metaanalysis. Audiology, v. 38, n. 2, p. 61-68, 1999.

PETRONE, L. Nivel de desconforto e limiar do reflexo acústico: estudo comparativo em trabalhadores expostos e não expostos a ruído. 1999. 59f. Monografia (Especialização) - Universidade Federal de São Paulo, São Paulo, 1999. p.59.

PIZARRO, G.; PIZARRO, G.U. Diagnostico clínico pela audiometria ocupacional. Rev. Acta WHO, v. 19, n. 1, p. 193-202, 2000.

UHLES, M.L.; CLARK, W.W.; ANCH, M. Effects of alcohol on the acoustic reflex thresshold in the chinchilla. Acta Otolaringol., v. 120, n. 4, p. 523-528, 2000. 